medical services provided in order to receive funds on the principle of «money follows patient», according to predetermined packages of medical services (by the way, their list is still limited, and does not allow to take into account all the variety of forms of manifestation of pathology); medical services aimed at those conditions, that cause the highest death rate or significantly worsen the quality of life (treatment of acute cerebral stroke, acute myocardial infarction, assistance in childbirth and neonatal care, early diagnosis of cancer) will be paid at an increased rate, which is also justified in terms of improving the medical and social effect in the context of the limited resources of the NPUCs; at the same time, other medical branches will continue to stagnate due to limited funding; special attention should be paid to the NHSU tariff rate for the provision of health care services, which is mainly several times lower, than their actual cost, due to which, patients will be either «under-treated», or forced to "cover the difference» at their own expense (the latter to some extent contradicts the declaration on "providing free basic health care»); in addition, if a patient makes a complaint about this fact to the NHSU, they may refuse to compensate the NPUC for such a clinical case at all; the latter, incidentally, also applies to medical data improperly filled into e-Health; the NHSU is trying to encourage NPUCs to improve their staff skills and logistics with higher tariffs, although the above seems problematic without attracting investment, and, nowadays, only certain segments of the health sector are attractive for investment;

- organization of hospital districts - functional associations of NPUCs (first of all, support multi-profile hospitals), which patients can reach by road within 60 minutes, will allow to regulate the provision of medical services to some extent; however, for people living in rural areas (especially those in remote areas) (especially given the mainly terrible condition of roads, lack of regular bus routes and their own vehicles), this means, that access to health services is reduced (with fatal consequences in emergency cases);

- changing the approach to appointing a NPUC leader is a situation, where a NPUC can be headed by a person without medical education, but who has a manager's education, on the one hand, is a classic example of crisis management, and on the other hand, is a "time bomb", because such a person is likely to simply not know the nuances of medicine (and, as we know, they are the "cause of loud successes and failures»); in addition, this area, unlike «classical business», is dominated by social, rather, than economic function; however, this is not yet a major problem, as most current NPUCs managers already have or are in the process of having a manager's education;

- formation of the development strategy of NPUCs - the head of a NPUC elected on a competitive basis must propose not only a business plan for its development, but also find investors for its implementation; however, in the current situation, a limited list of segments of the medical services market is attractive for investment, while others look doomed.
Of course, the above list of positive and negative effects of medical reform in Ukraine is not exhaustive, and, therefore, it can be continued. However, it is needed not for criticism (it is common knowledge, that "only he who makes no mistakes, makes nothing»), but, to find ways to address existing and possible problems in this area, including, by the improvement of the cooperation between scientists and healthcare practitioners, representatives of public administration, local government, business, public organizations and the general public.

Taking into account the abovementioned realities, it is necessary to propose conceptual approaches to the improvement of public management of health sector development:

1. The medical reform is not an end in itself, but a way of public management of health development; other related processes should be taken into account:

- globalization - «erasure of borders» in the movement not only of capital, qualified personnel, technologies, material and technical and other resources, but also of pathologies, to which neither domestic medicine, nor the immunity of our compatriots are yet ready; the potential for the development of medical tourism should be noted separately;

- scientific and technological progress - emergence of new technologies, equipment, tools, materials, medicines, etc., the proper use of which can help to combat existing and new pathologies; a significant increase in the importance of service and capital intensity, especially of highly specialized medical services;

- urbanization - the above processes, combined with the existing disproportions in the development of territories, are likely to only accelerate the concentration of the population in metropolices with the simultaneous decline/elimination of those settlements, where there are problems with income generation and the existing stagnation of social infrastructure facilities;

- demographic crisis - the decline in the share of able-bodied population against the background of large-scale labor migration makes it even more difficult for the state to fulfill its constitutionally established social functions; the aging of the nation aggravates the problem of increasing share of diseases inherent in old age and the need to combine medical and social services;

- macroeconomic situation - mass poverty, a wide income gap for certain segments of the population, poorly managed inflation and the national currency rate, industrial decline, a large-scale shadow economy and other factors make it almost impossible to develop medical insurance, and also secured Ukraine's status as a "Third World country», in which only speculative capital «enters» (as it is known, for the realization of economic, not social purposes), so it is worth expecting the implementation of mainly «niche» projects (in particular, opening of narrow or low-profile representative offices of well-known foreign clinics);

- incomplete distribution of property rights in business - there is still a high probability (as it used to be in industry, agriculture, etc.), that the majority of NPUCs (including 
due to inability to compensate for the loss of budget financing with their own revenues) may be on the verge of bankruptcy; under such conditions, liquidation (by the way, this option is most likely for depressed territories) or reorganization (on the basis of public-private partnership and in accordance with the abovementioned business plan of the NPUCs) is likely to happen; the investor will «enter» a NPUC and «take control» of its most profitable segments; - specialization - its deepening (based on the existing advantages) is one of the real options for the first survival and later development of NPUCs.

2. The Ministry of Health and NHSU should develop, approve, and, then consistently implement the «Strategy of Healthcare Reform in Ukraine», which should contain clear goals, terms and means of their achievement, distribution of powers, incentives and responsibility of performers; organically combine administrative, economic, organizational, legal and socio-psychological methods of public influence on the participants of this process.

3. The key to the further development of Ukraine's healthcare sector should be the comprehensive use of public management tools, aimed at the following:

- ensuring macroeconomic stability, increasing real incomes of the population and protecting economic entities to increase the investment attractiveness of NPUCs;

- development of public-private partnership, an important component of which is co-financing by the state, local authorities and business representatives of investment projects aimed at developing NPUCs and increasing the availability of quality of medical services;

- regulation of NPUCs activities to protect the interests of both their personnel (prevention of artificial bankruptcy, violations of labor laws) and patients (quality control of medical services and price monitoring);

- segmentation of medical services according to age, pathology and solvency of patients;

- facilitating the merger of NPUCs and/or deepening their specialization, which will be accompanied by the concentration of medical personnel and equipment on specific locations;

- educating NPUC managers and medical staff, as well as the public about the features and consequences of the medical reform; special attention should be paid to those territories, where the NPUCs are likely to be shut down or eliminated (in particular, "compensatory» measures within their hospital district should be envisaged: providing the public with routes and means of transport to the multidisciplinary referral hospital, facilitating the employment of medical staff, supporting IE doctors);

- the completion of the procedure of concluding declarations between primary doctors and patients as a guarantee of their access to free primary health care;

- a substantial (in accordance with the actual number of medical services provided) increase in the salaries of doctors of «narrow specialization» of all levels, will make it possible to secure the NPUCs outflow of qualified personnel and maintain high motivation for professional growth;
- expanding the list of medical service packages and bringing the size of the NHSU tariff for their provision in line with real costs;

- informing all the participants of this process, that the share of private medicine will increase every year (including through the «arrival» of foreign clinics), and a clearly regulated limited list of free medical services will be available.

\section{CONCLUSIONS}

At present, nobody needs to be persuaded in the necessity of the medical reform in Ukraine. The reform calls for the formation of the "vector» of changes, establishment of the National Health Service of Ukraine (NHSU), reorganization of medical institutions into non-profit public utility companies (NPUCs), as well as the autonomisation and commercialization of them, and also inducement to making agreements with NHSU, reforming first the primary link, and later the secondary and the tertiary ones, organization of hospital districts etc. Nevertheless, a great number of questions remains concerning on-going and probable medical, social, and economical effects, caused by misuse of the methods of public management of healthcare development. The medical reform is not a goal in itself, but when implementing the reform, it is necessary to consider other related processes, such as globalization, technological progress, urbanization, demographic crisis, macro-economic situation, unfinished distribution of the rights of property in business, specialization. Now, there is «The Strategy of the Reformation of Healthcare of Ukraine». And the proper use of the complex of methods of public administration, directed both at balanced growth of the national health field, and prevention of negative influence of related sectors and fields of national economy guarantees its successful realization.

The continuation of scientific researches on this issue will contribute to the further development of the national health sector, including by improving the public management of this component of the national economy.

\section{REFERENCES}

1. Ofitsiynyy sayt Derzhvnoyi sluzhby statystyky Ukrainy [Official website of the State Statistics Service of Ukraine]. 2019. http://www.ukrstat. gov.ua/operativ.(in Ukrainian).

2. Bohomolets 0. 2017. liveam.tv/subektivnye-itogi-dnya.html. (in Ukrainian).

3. Nashi mediky vyezzhayut za hranitsu [0ur healthcare specialists are traveling abroad]. 2017. https://gazeta.ua/ru/articles/commentsnewspaper/_nashi-mediki-vyezzhayut-za-granicu/235847. (in Russian).

4. Shkrobanets I.D., Biduchak A.S., Kardash E.V. Study of public opinion of patients concerning availability, satisfaction of rendering medical services and attitude to reforming public health. Clinical and experimental pathology. 2013; 12(4): 155-7.

5. Ukraina na $94-m u$ mistsi zi 195 v Hlobalnomu indeksi bezpeky zdorobya [Ukraine took the 94th place out of the 195 places in the Global Health Security Index]. 2019. https://www.radiosvoboda.org/a/newshlobalnyi-index-bezpeky-zdorovya/30235911.html. (in Ukrainian). 
6. Ofitsiynyy sayt Ministerstva okhorony zdorovya Ukrainy [Official website of the Ministry of Health of Ukraine]. http://www.moz.gov.ua/ua/ portal/. (in Ukrainian).

7. Melnychenko 0.A., Udovychenko N.M. Metody ta zasoby publichnoho upravlinnya rozvytkon sfery okhorony zdorovya [Methods and Tools of Public Administration of the development of Healthcare]. Bulletin of National university of Civil defence of Ukraine. (State management). 2018;1:154-162. https://doi.org/10.5281/zenodo.1240832. (in Ukrainian).

8. Ruden V.V. An innovative technology «The audit of health status of individuals/community» at the primary level of medical care as a basis in the process of transformation of the medical branch to economic methods of population health management under the conditions of decentralization in Ukraine. AML. 2017; 23:65-71. D0l: https://doi. org/10.25040/aml2017.03.065.

9. Simonet D. The New Public Management Theory in the British Health Care System: A Critical Review. Administration \& Society. 2013;6. https:// doi.org/10.1177/0095399713485001.

10. Mei J., Kirkpatrick I. Public hospital reforms in China: towards a model of new public management? International Journal of Public Sector Management. 2019; 32(4): 352-66. https://doi.org/10.1108/ IJPSM-03-2018-0063.

11. Tabriz J.S., Goshayie E.H., Doshmangir L., Yousefi M. New public management in Iran's health complex: a management framework for primary health care system. Cambridge University Pres. 2018. https:// doi.org/10.1017/S1463423617000767.

\section{ORCID and contributionship:}

Oleksandr A. Melnychenko: 0000-0001-5021-9025 A, B, C, D, E, F

Ganna O. Chovpan: 0000-0002-3619-2927 A, B, D, E, F

Nataliya M. Udovychenko: 0000-0002-5431-3016 ${ }^{\text {A, D, E, F }}$

Georgii R. Muratov: 0000-0002-5865-3747 A, D, E, F

Zhanna D. Kravchenko: 0000-0003-1692-4665 A, B, E, F

Elena H. Rogova: 0000-0003-4482-0847 A, B, E, F

Zhanna M. Kutuzyan: 0000-0002-1729-6325 A, B, E, F

\section{Conflict of interest:}

The Authors declare no conflict of interest.

\section{CORRESPONDING AUTHOR}

Oleksandr A. Melnychenko

Kharkiv national medical university

4 Nauki av., 61022 Kharkiv, Ukraine

tel: +380501627350

e-mail:mel_doc@ukr.net

Received: 14.12 .2020

Accepted: 29.03.2021

A - Work concept and design, B - Data collection and analysis, C - Responsibility for statistical analysis,

D-Writing the article, $\mathbf{E}$ - Critical review, $\mathbf{F}$ - Final approval of the article 


\title{
INVOLVEMENT OF MEDICAL PROFESSIONALS IN THE INVESTIGATIVE PROCEDURES DURING THE DETECTION OF CERTAIN TYPES OF CRIMES
}

DOI: 10.36740/WLek202105131

\author{
Alexander M. Bidei', Oleksandr I. Kozachenko ${ }^{2}$, Mykola 0. Gelemei ${ }^{3}$ \\ 'DEPARTMENT OF LAW, PHILIP ORLIK INTERNATIONAL CLASSICAL UNIVERSITY, MYKOLAIV, UKRAINE \\ ${ }^{2}$ EDUCATIONAL-SCIENTIFIC INSTITUTE OF LAW NAMED AFTER VOLODYMYR THE GREAT, KYIV, UKRAINE \\ ${ }^{3}$ PRECARPATHIAN DEPARTMENT (IVANO-FRANKIVSK) OF THE NATIONAL ACADEMY OF INTERNAL AFFAIRS, IVANO-FRANKIVSK, UKRAINE
}

\begin{abstract}
The aim: To clarify the importance of the need to involve medical professionals, as experts, in the conduction of the investigative actions during the pre-trial investigation of certain types of crimes.

Materials and methods: This research is based on the general laws and categories of the Cognition theory and on the framework of materialistic dialectics; it uses a comprehensive approach to the study of the problems under consideration, applies systematic, statistical, historical, legal and comparative legal methods.

Conclusions: The need to use specialized medical knowledge depends not on a certain type of crime, but on the specific circumstances of the committed criminal offense. Based on theoretical and practical frameworks, the reasonable practical significance of using specialized medical knowledge during a pre-trial investigation expands and deepens the possibilities of procedural evidence, contributes to the rapid and complete crime disclosure, exposing the wrongdoers and making the right decisions in criminal proceedings.
\end{abstract}

KEY WORDS: specialized knowledge, medical specialist, forensic medical examination

Wiad Lek. 2021;74(5):1213-1218

\section{INTRODUCTION}

According to Art. 3 of the Constitution of Ukraine, man, his rights and freedoms are of the highest value, and the state as the main guarantor, which entrusted with the obligation to recognize, respect and protect them. One of the most important rights enshrined at the constitutional level is the right to life (art. 27, para. 1), the right to liberty and integrity (art. 29), and the right to judicial protection by the State against criminal offence (art. 56) [1].

Nowadays, criminal proceedings are characterized by significant scientific intensity. The commission of crimes, in increasingly sophisticated ways, requires adequate methods and techniques for their disclosure. Knowledge in various fields of science and technology has significantly expanded, which opens new opportunities in their use during investigating of various crimes. At the same time, the investigator, with the help of specialists in the field of forensic medicine, has the opportunity to solve such rather complex tasks as determining the exact time of a particular investigative action, identifying their sequence, as well as planning and optimal implementation of them.

The expert in the forensic medicine also plays a vital role during the pre-trial investigation, since it is he who can help to expose evidence of a crime that is difficult to the investigator, create a model of criminal actions, as well as suggest a sequence of certain investigative actions aimed at solving a crime, exposing real criminals, as well as establishing other circumstances that have to be proved in criminal proceedings (Article 91 of the Code of Criminal Procedure). At the same time, under the amendments adopted by the VerkhovnaRada aimed at the introduction of an integrated organ transplantation system in Ukraine [2], the need for the use of special forensic knowledge in the conduct of pre-trial investigations is increasing, which leads to the promptness and relevance of this study.

\section{THE AIM}

The purpose of the article is to clarify the importance of the involvement of medical workers as the experts in conducting investigative actions during the pre-trial proceedings of certain types of crimes.

\section{MATERIALS AND METHODS}

To achieve the goal, according to the subject of research, the methodological basis was the general laws and categories of the Cognition theory and framework of materialistic dialectics. This research uses a comprehensive approach to the study of the problems under consideration, using a systematic method to investigate the state of involvement of medical workers in investigative procedure in the conduct 
of pre-trial procedures; historical, legal and comparative legal methods - to analyze the regulatory framework for the involvement of medical experts to determine the effectiveness and feasibility of such involvement in modern conditions; statistical - to collect and analyze empirical data about cases of involvement of medical professionals during a pre-trial investigation in order to confirm the representativeness of the findings.

\section{REVIEW}

Today, it is impossible to achieve a high quality of crime investigation "without applying knowledge in various fields of science and technology in its production" [3, p. 7]. Forensic science aims to achieve a state in which a set of means and methods of investigating crimes is in unity with the science of criminal procedure and would constitute a single legal mechanism that can provide the solution for criminal proceedings specified in Art. 2 of the Code of Criminal Procedure [4].

The evidential process in criminal proceedings is confirmation by the relevant evidence of the adequate and objective reproduction and display of the actual circumstances of the crime. And this, in turn, is the acquisition of true and reliable knowledge about the subject of evidence. The proof is part of the process of knowing the truth, but in such a specific area of activity as the investigation of crimes. According to V.V. Tishchenko:..." knowledge in the investigation proceeds in the form of procedural evidence - that is, activities carried out in the manner prescribed by law by collecting, studying and evaluating evidence " $[5$, p. 158].

However, knowing the whole picture of a criminal act in criminal proceedings is a complex process of studying not only material objects, their interaction, as well as socially organized matter - personality, thinking and behaviour. Therefore, to fully, comprehensively and objectively investigate the criminal act, individuals involved in the investigation must have deep knowledge, including specialized, as well as professional experience. In the cognitive process, practical and mental aspects of activity are combined [6, p. 18].

As noted by I.V. Ozersky, the decision making are always due to the appropriate level of knowledge, since the cognitive process in criminal proceedings is the process of obtaining information about the facts included in the evidence, with which the law connects the adoption of specific procedural decisions by the essence of the actual motives of the decision made $[7$, p. 58].

The improvement of scientific methods of criminal procedure, in particular, required the wide use of specialized knowledge by other experts who were involved in the investigation of crimes, began to specialize in certain types of activities, which served to create relevant special knowledge: forensic, medical, accounting, psychological and other [8, p. 149].

An analysis of regulations shows that in some scientific fields, for example, such as medicine, research uses only those tools and methods that are implemented by relevant legal norms. These procedures should be carried out by specially authorized experts: doctors, forensic experts under their competence and with special knowledge. Departmental regulations in some cases also regulate the terms of scientific research.

Special knowledge constitutes a set of scientifically-based information, which is held by the person (experts and specialists) in various fields of science, technology, art and craft, and under the norms of legislation are used to successfully resolve the tasks of criminal proceedings [9, p. 190-191].The use of specialized knowledge is possible in the investigation of any crime if it is possible to discover or explain its circumstances. Specialized knowledge can be used to create a sufficient evidence base depending on the particular investigative situation and facts of the case $[9$, p. 188].

Specialized knowledge is an important procedural institution that establishes the areas for the participation of expert in the investigation of crimes, as well as the conditions for the application of knowledge from non-legal industries in criminal proceedings [10, p. 26].

Particular threat among crimes against the person is those that meddle with human life and health. According to statistics in 2019, compared to 2014, the number of recorded crimes against human life and health increased by more than $52.7 \%$ (statistics 2014-2020 as shown in figure). However, in 2020 there was a decrease in the number of registered crimes 37328 , which may indicate a low level of involvement of medical workers in investigative actions at all stages of criminal proceedings (Fig. 1).

The peculiarities of the investigation of such crimes depend on objective and subjective factors. First of all, this applies to a wide variety of ways of saving a person's life or causing bodily harm, directly affects the investigation and causes the active use of specialized knowledge, primarily in the field of medicine, in choosing means and methods of studying material objects to obtain information necessary to establish the circumstances of the incident and the person who committed such a crime [10, p. 4]. An important characteristic of specialized medical knowledge in criminal procedure is the purpose of their use [11, p. 48]. A clear definition of it at each stage of criminal proceedings is important for a correct understanding of the duties and capabilities of persons using certain types of knowledge in the procedural forms prescribed by law [12, p. 40].

In the legal literature, there are different approaches to substantiating the purpose of crime investigation. So, from the position of M. Cheltsov-Bebutov and S. Golunsky, the purpose of the criminal process in the fight against crime [13, page 6]. V. Tomin notes that the purpose of the criminal process is to expose persons guilty of a crime, to apply adequate punishment to them or other measures of State that ensure, in a specific case, the achievement of the goal of criminal proceedings without sentencing [13, p. 47]. However, the dominant position was the one justified by M. Strogovich and later supported by many scholars [14, p. 135], according to which the purpose of the criminal process is to establish the truth in a criminal case $[15, \mathrm{p} .40]$. 


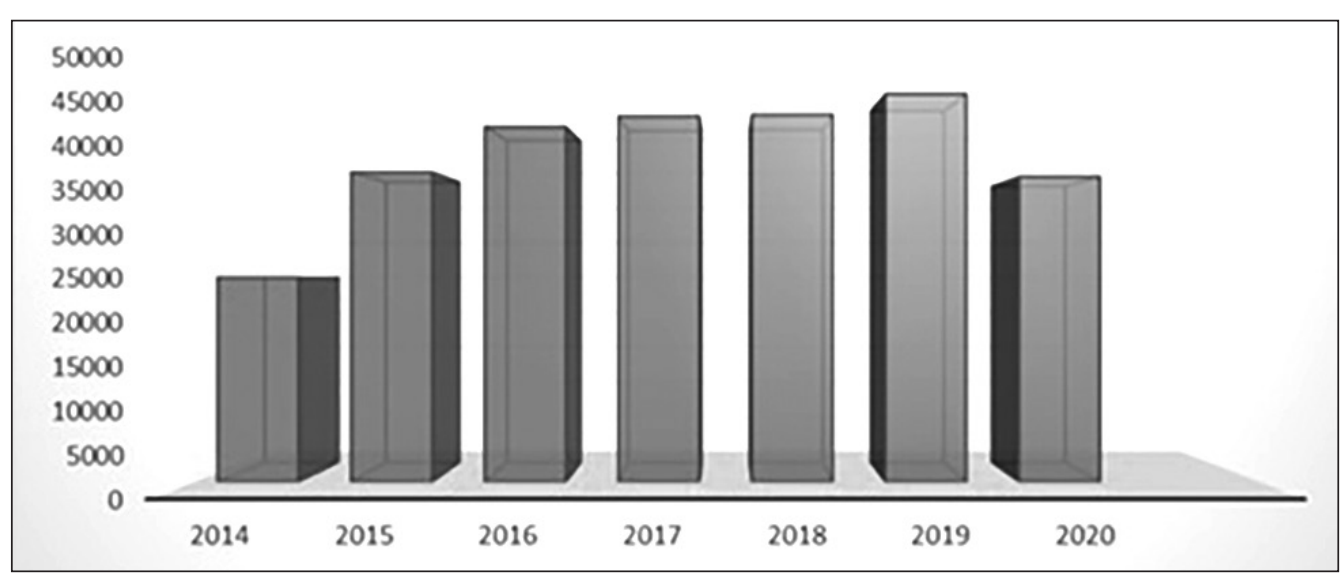

Fig. 1. The number of registered crimes against life and health of a person in the 2014-2020 years
Specialized medical knowledge is used as evidence and carried out under the procedure prescribed by law, as well as for non-procedural application in conducting operational-search measures and other non-procedural actions [16, p. 18; 27, page 48].

The importance of specialized medical knowledge used in criminal proceedings consists of many aspects, the key of which, according to V. Yu. Stetsenko, are as follows:

1) the field of their implementation is not limited to any stage of the criminal process. They are widely used in various forms throughout the process to meet the challenges of each stage and the judicial process as a whole;

2) they can be applied in all elements of the evidentiary process - in the collection, verification and evaluation of evidence;

3 ) the evidentiary role of specialized medical knowledge is determined by the need and possibility of using them to establish circumstances of criminal legal significance, their importance in establishing the circumstances included in the subject of evidence in criminal proceedings. With the help of special medical knowledge, an act of a crime, circumstances affecting the degree and nature of responsibility of the accused, as well as circumstances contributing to the commission of the crime can be established [17, p. 57].

Specialized medical knowledge plays an important role in the implementation of criminal justice tasks. Their application expands and deepens the possibilities of procedural proof, helps to quickly and fully solve crimes, expose the perpetrators and make the right decisions in criminal proceedings. Specialized medical knowledge is also important in crime prevention [17, p. 56].

The purpose of specialized medical knowledge is also to facilitate the collection of evidence and guidance for the investigation and prevention of crime, as well as the development of technical and tactical means and methods for its collection [6, p. 18;27, page 48]. Specialized medical knowledge is essential for proving specific factual circumstances in the investigation of a crime. So, you can interrogate the surgeon who treated the wound or performed the operation, about the direction of the wound canal, its depth, width and thereby establish approximate dimensions of the crime weapon. Such information is essential for obtaining evidence as a result of forensic examination, since it is difficult to establish it after treatment.

We share the opinion of N. I. Klimenko, that the issue of the targeted use of specialized knowledge is closely related to the forms of their use in the investigation of crimes. When highlighting the forms and use of specialized knowledge in the investigation of crimes, they proceed from an analysis of the norms of the Code of Criminal Procedure of Ukraine, which determine the rights and obligations of entities involved in certain procedural actions. However, the purpose of their application should also be taken into account, as well as the methods of implementation [19, pp. 129-130].

The main objectives of the use of specialized medical knowledge can be defined as the assistance for a complete and rapid investigation of crimes; establishing the truth in the case; studies of certain objects and phenomena; obtaining the necessary information to establish the circumstances relevant to the accurate decisions in the case; facilitating the identification, recording and seizure of evidence and the identification of special issues arising from investigative actions; development of technical and tactical means and methods of evidence collection. The non-use of special knowledge or its improper use in conducting investigative actions is a significant factor that reduces the quality and effectiveness of the pre-trial investigation, and sometimes leads to tactical errors, misjudgments and making misguided decisions [20, p. 40]. When deciding to use specialized medical knowledge, the investigator must take into account the specific circumstances of the criminal proceedings, determine the form of use of this knowledge. "By necessity," notes A. G. Shlyakhov, "here is understood the need to solve issues using special knowledge" [21, p. 62].

The purpose of engagement a subject-matter expert in investigative actions is to expand the practical capabilities of the investigator in the qualified conduct of certain investigative procedure, while achieving a complete, objective and comprehensive picture of the incident, to assist with professional knowledge and skills in identifying, fixing and seizing objects that can be evidence. A peculiarity of this form of specialized knowledge application is that the law differentiates between two types of their participation in investigative actions - optional and mandatory. The optional 
participation of a specialist is provided for in Art. 71 of the Code of Criminal Procedure. The specialist is not always involved by the investigator, but only when necessary [4].

Bringing attention to crimes, where investigators can use the special medical knowledge of experts, we can see how the use of this knowledge can help in such activities (from crimes against the national security of Ukraine to crimes against the peace, mankind and international law and order). The necessity of specialized medical knowledge use depends not on a certain type of crime, but on the specific circumstances of the criminal offense committed. But, along with it, being guided by the division of crimes given in the Criminal code of Ukraine, we can allocate the most typical crimes which investigation is difficult to conduct without the use of specialized medical knowledge.

\section{DISCUSSION}

So, use of specialized medical knowledge is necessary at investigating crimes against life and human health (premeditated murder, premeditated murder by mother of the newborn child, deliberate bodily injury, a beating, tortures, the crimes committed by health workers, etc.); against freedom, honour and dignity of the personality; against sexual freedom and sexual integrity of the personality (rape, the depravity of minors); in the field of trafficking in narcotic drugs, psychotropic substances, their analogues or precursors and other crimes against public health; against the state authorities, local self-government and citizens' associations (encroachment on the life of a law enforcement officer, member of a public formation for the protection of civil order); in the field of official activity (abuse of power or official authority, official forgery of medical documents). The effect of the using modern medical science achievements is undergone primarily by the evidence practice in criminal proceedings. The importance of specialized medical knowledge is significant and can be used by the investigating authorities and the court in the process of collecting, researching and evaluating evidence, in determining the circumstances constituting the subject of evidence [17, p. 57]. For example, the successful investigation of such serious crimes as the encroachment on the life of a law enforcement officer (article 348 of the Criminal Code of Ukraine) depends on the proper use of specialized knowledge, especially in the field of forensic medicine. According to St 241,242 Codes of Criminal Procedure special knowledge can be used by conducting forensic medical examinations, medicolegal survey, involvement of the medical experts in investigating actions. With the help of forensic knowledge, answers can be obtained to important questions for criminal proceedings: the time of death and bodily harm, the causes, nature and severity of bodily harm, the presence and group signs of traces of biological origin, etc. [4;23, page 78]. So, during the investigation of criminal offences in the form of an attack on the life of law enforcement officers and members of their families, the registered number of which is 2013-2017 indicates the absence of a descending trend, the investigator must necessarily involve forensic experts. Because, the expert during the investigative actions should help investigative authorities not only to inspect the scene of the incident, the corpse, but also find traces of the crime (for example, traces of biological origin - blood, hair, etc.), various objects (loop, weapon), and remove them without harm. Secondly, according to the specifics of the investigation of this category of crimes, investigative examination and forensic examination are closely interconnected, and therefore the completeness and proficiency of the expert's conclusions depend on the chosen tactics of their conduct and therefore influence the objectivity of the investigation of this category of criminal proceedings [23, p. $78 ; 24$ pages 185$]$.

Another example of the use of specialized knowledge of experts in the conduct of interrogation in the investigation of crimes in the field of trafficking in narcotic drugs, psychotropic substances, their analogues or precursors (art. $305,307,309,311,314,319,321,325,326$ of the Criminal Code of Ukraine). In the investigation of these crimes, especially those committed by organized criminal groups, as a rule, specialists in the field of chemistry are well aware of the technologies for the narcotic substances production, medicines, and the cultivation of drug-containing plants. Therefore for appropriate cross-examination of such persons, survey, an inspection of the scene and an investigative experiment, the persons with equal specialized knowledge have to be involved [25, page 41$]$.

So, among the specialists involved in such investigative action as cross-examination, pharmacists who have knowledge of the physicochemical properties of medicines, technologies for making drugs and other means based on them, expert chemists of the departments of examination of narcotic drugs, psychotropic substances, their analogues and precursors, drug abuse therapists can be involved. These specialists during interrogation can help with the following:

1) interpret the information reported by the interrogators, who operate in the testimony in special terms; 2 ) it is more correct to formulate the question, to develop an interrogation plan; 3 ) provide an accurate assessment of the special rules; 4) collect data that may be necessary for conducting examinations, as well as formulate appropriate expert tasks; 5) prevent false testimony on special issues; 6) objectively and accurately record the testimony of the interrogated person; 7) determine the state of the interrogated person at the time of preparation for interrogation (intoxication or withdrawal - the so-called withdrawal syndrome) and the opportunity to participate in it (in a situation of drug use by a person); 8) take samples for examination in the case when during interrogation a person was convinced of the need to provide certain samples willingly [25, p. 41-43].

Also, the participation of the judicial expert in the interrogation will be useful in clarifying the relationships of the detected traces, objects, phenomena or situations under investigation, checking previously established investigative and expert data, establishing contradictions between them, finding out additional information and output data necessary for the proper organization of forensic examinations 
[25, p. 43]. The assistance of a specialist of a forensic expert who conducted an appropriate examination in criminal proceedings can be effective. The expert involved this way explains the significance of the examination conclusions, detail the features of the research process, explains the methodology and decide whether previous expert conclusion does not contradict with circumstances revealed during other investigative actions.

\section{CONCLUSIONS}

Thus, we can conclude that the prompt and informed use of specialized medical knowledge, which is used to find, detect, remove, secure data in evidence, significantly increases the possibility of identifying the facts necessary to establish the truth at the stage of pre-trial investigation of criminal offenses.

Thus, we can conclude that ensuring the proper procedural and forensic quality of individual investigativeactions is impossible without the appropriate useof the forensic science and medicine. The study confirmed that forensic experts play an important independent role in the pre-trial investigation becausethey can help in detecting traces of a crime that could be concealed from the investigator, in reenacting crime scene and crime reconstruction, recommend certain investigative actions aimed to solve a crime, to incriminate a specific person, as well as to set up other circumstances to be proved in criminal proceedings. At the same time, it is very important to understand the role and placeof involving medical experts at each stage of the criminal process, as long as their functions and powers in the procedural forms provided by law. It has been proved that the decision to use specialized medical knowledge does not depend on a type of crime, but relies on the specific circumstances of the committed crime. So the prompt and reasonable use of specialized medical knowledge in searching, detecting, seizing, consolidating evidence data,significantly increases the possibility of identifying the facts necessary to establish the truth at the stage of pre-trial investigation of criminal offenses.

\section{REFERENCES}

1. Constitution of Ukraine. № 2222-IV 08.12.2004. https://zakon.rada. gov.ua/laws/show/254k/96-вp\#Text. (in Ukrainian).

2. Zakon Ukrayiny pro zastosuvannya transplantatsiy anatomichnykh materialiv lyudey. [Law of Ukraine On Application of Transplantation of Anatomical Materials to a Person]. https://zakon.rada.gov.ua/laws/ show/2427-19\#Text. (in Ukrainian).

3. Zakatov A. A., Oropay Y. N. The use of scientific and technical means and special knowledge in the investigation of crimes. Kyiv. RIO Ministry of Internal Affairs of the Ukrainian SSR. 1980; 104.

4. Kryminal'nyy protsesual'nyy kodeks Ukrayiny: zakonodavstvo pro zakonodavstvo iz zminamy ta dopovnennyamy vid 19.02.2019 r.: ofits. tekst. [Criminal Procedure Code of Ukraine: Law of Ukraine from 19.02.2019: official text]. Kyiv. Alerta. 2019; 324. http://zakon2.rada. gov.ua/laws/show/4651-17. (in Ukrainian)

5. Tishchenko V.V. Koryslyvo-nasyl'nyts'ki zlochyny: kryminalistychnyy analiz: monohrafiya. [Violent crimes: forensic analysis: monograph]. Odesa. Yurydychna literature. 2002; 360. (in Ukrainian).
6. SemenovV.V.Spetsial'ne znannya v rozsliduvanni zlochyniv: dys.... kand. yuryd. nauk: 12.00.09. [Specialized knowledge in the investigation of crimes: dissertation of Candidate of juridical sciences: 12.00.09]. Kyiv. 2006; 212. (in Ukrainian).

7. Ozersky I. The prosecutor's use of psychological knowledge while maintaining public prosecution in court: monograph. Poltava. 2008; 368.

8. Taranova A.M. Formy vykorystannya spetsial'nykh znan' pry rozsliduvanni nenalezhnoho vykonannya profesiynykh obov"yazkiv medychnym abo farmatsevtychnym pratsivnykom. [Forms of the use of specialized knowledge in the investigation of breach of professional duties by a medical or pharmaceutical worker]. Pidpryyemstvo, hospodarstvo ta pravo. 2019; 10: 198-203. (in Ukrainian).

9. Byshevets A.V. Vykorystannya spetsial'nykh znan' pry dovedenni do kryminal'nykh provadzhen'. [The use of specialized knowledge in evidence in criminal proceedings]. Visn. krymin. sudochynstva. 2015; 2: 187-193. (in Ukrainian).

10. Galdetskaya I. G. Pravovi ta naukovi osnovy vykorystannya spetsial'nykh medychnykh znan' pry rozsliduvanni zlochyniv: dys. ... kand. yuryd. Nauk. 12.00.09. [Legal and scientific foundations of the use of special medical knowledge in the investigation of crimes 12.00.09]. Kyiv. 2011; 231. (in Ukrainian).

11. Chaplinsky K. A., Chaplyns'kyy K. 0. Naukovi pidkhody shchodo vyznachennya ponyattya ta osoblyvykh spetsial'nykh znan' u kryminal'nomu sudochynstvi. [Scientific approaches to the definition of the concept and essence of special knowledge in criminal proceedings]. Aktual'ni pytannya teoriyi ta praktyky kryminalistychnoyi nauky: zbirnyk materialivVseukr. nauk.-prakt. konf., prysvyachenoyi 50-richniy kafedri kryminalistyky ta sudovoyi medytsyny Natsional'noyi akademiyi vnutrishnikh sprav (Kyiv, 23 January 2015). Kyiv. Vydavnychyy dim "Hel'vetyka», 2015; 37-41. (in Ukrainian).

12. Cheltsov-Bebutov M. A. Soviet criminal trial. Kharkov, 1927; 1300.

13. V.T. Selected works. St. Petersburg. Yuri. Press Center, 2004; 586.

14. Paliashvili A. Y. Ekspertyza za uholovnym dilom. [Criminal expertise]. Moscow. Yuri. lit, 1973; 144. (in Ukrainian).

15. Strogovich M. S. Course of the Soviet criminal process. 2 toms. Moscow: Science. T. 1: Main provisions of the science of the Soviet criminal process. 1968-1970; 470.

16. Semenov V.V. Spetsial'ne znannya v rozsliduvanni zlochyniv. [Special knowledge in the investigation of crimes]. Kyiv. 2006; 212. (in Ukrainian).

17. Stetsenko V.Yu. Vykorystannya spetsial'nykh medychnykh znan' u holovnomu sudovomu vyrobnytstvi. [Use of special medical knowledge at the criminal court]. Moscow. 2004; 189. (in Ukrainian).

18. Klimenko N. I. Tsili vykorystannya spetsial'nykh znan' u rozsliduvanni zlochyniv proty zhyttya ta zdorov'ya lyudyny izzastosuvannyam VRiVP.. [Goals of using special knowledge in the investigation of crimes against human life and health using BP and OP]. Aktual'ni problemy derzhavy ta prava: zb. nauk. pr. Odesa. 2000; 8: 129-134. (in Ukrainian).

19. Chaplyns'kyy K. O. Naukovi pidkhody shchodo vyznachennya ponyattya ta osoblyvykh spetsial'nykh znan' u kryminal'nomu sudochynstvi. [Scientific approaches to the definition of the concept and essence of special knowledge in criminal proceedings]. Aktual'ni pytannya teoriyi ta praktyky kryminalistychnoyi nauky: zbirnyk materialiv Vseukr. nauk.-prakt. konf., prysvyachenoyi 50-richniy kafedri kryminalistyky ta sudovoyi medytsyny Natsional'noyi akademiyi vnutrishnikh sprav (Kyiv, 23 January 2015). Kyiv. Vydavnychyy dim «Hel'vetyka». 2015; 37-41. (in Ukrainian). 
20. Shlyakhov A.R. Orhanizatsiya ta vyrobnytstvo kryminalistychnoyi ekspertyzy v SRSR. Teoriya i praktyka kryminalistychnoyi ekspertyzy. [Organization and production of forensic expertise in the USSR. Theory and practice of forensic examination]. Moscow. 1962; 9-10: 119. (in Ukrainian).

21. Husyeva V.0. Deyaki aspekty vykorystannya spetsial'nykh medychnykh znan' pry rozsliduvanni dosyahnennya zhyttya pratsivnykiv pravookhoronnykh orhaniv. [Some aspects of the use of special medical knowledge in investigating attacks on the lives of law enforcement officials]. Suchasni tendentsiyi rozvytku kryminalistyky ta kryminal'noho protsesu: tezy dop. mizhnar. nauk.-prakt. konf. do 100-richchya vid dnya narodzhennya prof. M. V. Saltevs'koho. Kharkiv. 2017; 77-78. (in Ukrainian).

22. Husyeva V.0. Rol' spetsial'nykh medychnykh znan' pry rozsliduvanni zlochyniv proty pratsivnykiv pravookhoronnykh orhaniv. [The role of special medical knowledge in the investigation of crimes against law enforcement official]. Visnyk Luhans'koho derzhavnoho universytetu vnutrishnikh sprav imeni YE. 0. Didorenka. 2017; 1: 183-188. (in Ukrainian).

23. Bondar V. S. Osoblyvosti vykorystannya spetsial'nykh znan' pry provedenni dopitu pry rozsliduvanni zlochyniv u sferi obihu narkotychnykh zasobiv, psykhotropnykh rechovyn, yikh analohiv abo prekursoriv. [Peculiarities of using special knowledge when conducting interrogation in the investigation of crimes in the field of trafficking in narcotic drugs, psychotropic substances, their analogues or precursors]. Naukovyy visnyk Khersons'koho derzhavnoho universytetu. Kharkiv. 2015; 5(4): 40-45. (in Ukrainian).

\section{ORCID and contributionship:}

Alexander M. Bidei: 0000-0003-0895-6923 A, D, C

Oleksandr I. Kozachenko: 0000-0003-1449-3670 F,D, B

Mykola O. Gelemei: 0000-0002-2608-9117 C, E, F

\section{Conflict of interest:}

The Authors declare no conflict of interest.

\section{CORRESPONDING AUTHOR}

Alexander M. Bidei

Philip Orlik International Classical University

2 Kotelna St, 54000 Mykolaiv, Ukraine

tel.: + 380507006312

e-mail: bideialexander57@gmail.com

Received: 12.12 .2020

Accepted: 29.03 .2021

A - Work concept and design, B - Data collection and analysis, C - Responsibility for statistical analysis, $\mathbf{D}$-Writing the article, $\mathbf{E}$ - Critical review, $\mathbf{F}$ - Final approval of the article 